\title{
Entrepreneurial Activity, Entry and Persistence of Firms: Econometric Analysis Based on Count Data
}

\author{
Syoum Negassi, Ghasem A. Shiri \\ Business School, Université de Paris1 Panthéon Sorbonne, Paris, France \\ Email: negassi@univ-paris1.fr
}

Received March 14, 2012; revised April 12, 2012; accepted April 19, 2012

\begin{abstract}
This study aims to assess the impact of technological specification and innovation dynamics in Schumpeterian perspective on the technological performance (innovation) of firms. Using an original data construction, our empirical analysis is carried out with patent and survey databases on French firms. We classify the various possible determinants of innovation into two groups of variables; firm-specific variables and sectorial-specific variables. We utilise patent data from European Patent Office (EPO) database (classified in 30 technological classes), survey of the R \& D resources and, firm's surveys in French (EAE) for French firms for the period 1993-2001. The results of our count data models show that entrepreneurial activity increases the innovation output and the sectorial-specific variables have an impact on patent application.
\end{abstract}

Keywords: Entrepreneurial Activity; Technological Entry; Innovation; Firm Size; Market Structure

\section{Introduction}

After six decades of scrutiny since the publication of Schumpeter's "capitalism, socialism, competition and innovation" in 1942, the determinants of innovation patterns are still a subject of intense debate. Recent studies propose a large variety of factors that determine innovation patterns. The life cycle of technology [1-3], institutional, national and cultural factors [4-6], local and regional factors [7-9], technological and sectoral factors [10-13] are proposed to explain the difference of innovation patterns. Recently, the researchers are more interested in sectorial and technological factors. On one hand these factors are easier to test empirically. On the other hand, the researchers show that the role of these factors in innovation determination is more important than other factors [14,15]. Opportunity conditions, appropriability and accumulation of knowledge, demand that conditions are the factors that have been studied more than others in the set of sectoral and technological factors. Entrepreneurial theory, as a recent framework for innovation understanding relies on these factors. The effect of firm formation and the effect of technological entry on innovation intensity, depend on technological factors. In fact, two sets of factors appear very important today as a source of innovation: the births of new firms or "start ups" and the innovation persisting of large firms. For some authors [16], the most fundamental shift that takes place in the industrialized countries is the emergence of an entrepreneurial economy. Newly created firms have spurred in many areas $[17,18]$. First, a particular emphasis is placed on firm's technological natality as a factor, which interacts with the pace of technological change in the evaluation of an economy. Second and parallel to the process of business formation, which has increased in many countries, a large part of technological activity in many sectors and in several countries has been attributed to persistent innovation of large firms. Many scholars [19, 20] have recently emphasized the second point.

These two trends raise new questions: is there an impact of the natality of new small firms (start-ups) on innovative intensity in the industrial sectors? If yes, is this impact general or specific to some technological areas (industrial sectors)? On the other hand, is the existence of large firms which innovate persistently (sometimes over period of a large time), a factor which determines (strongly or weakly) the innovation capacity of the sector and the firm?

In this paper, we will study these patterns at the microeconomic level.

To reach our aim, we conducted a special data pooling: each variable was calculated at the firm and at the technological class level. We have proposed empirical models with both firm-specific factors and technological regime indicators. These models allow us to examine the Schumpeterian dynamic of innovation in the presence of technological regime factors. Hence, the two aspects of creation of technology (technological natality and firm 
innovative persistence) are basically at the core of the Schumpeterian view of economic development. For us, natality means technological entry. This concept presents two phenomena: entry of new firms, which innovate for the first time (the birth of new firms), and entry of firms in new (for the firm) technological field, in which the firm innovates for the first time. The second case is associated with a strategy of technological diversity. Technological entry is associated with the entrepreneurial technological regime [21] or to Schumpeter Mark I model [22-24]. When the firms are small, the competition is strong, and the turbulence (entry and exit) is high. Firm persistence in innovation is related to the routine technological regime ${ }^{1}$ [21] or to the Schumpeter Mark 2 model $[23,24]$. When the firms are large, the oligopolistic competition is stable, and the turbulence is weak. We label these two regimes as the Schumpeterian dynamic; the first describes a model of creative destruction of firms and activities, and the second describes a model of creative accumulation of knowledge within the large persistently innovating firms, which develop dynamic competence [25].

The structure of the paper is as follows: Section 2 contains a review of theoretical framework and previous empirical literature. In the Section 3, we present the data, empirical models and statistical analyses of models. And finally, Section 4 concludes the finding.

\section{Theoretical Framework}

\subsection{Entrepreneurial Theory}

In the literature of entrepreneurial theory there are two approaches of entrepreneurial activity. In the first approach, entrepreneurship and innovation are virtually synonymous. Whereas the second approach suggests that the relationship between entrepreneurship and innovation is anything but trivial [26]. Entrepreneurial activity can be defined as "attempts to exploit opportunities that others have not identified or exploited" [27]. Geroski [28] attempted to understand whether or not the correlation between entry (firm formation) and innovation exists because entry stimulates innovation, or because new innovations open up market opportunities that small firms are either particularly quick or are unusually well suited for use. He proposes that market conditions (as opportunity condition) play a larger role in determining entry rates than determining innovation rates [28].

Entrepreneurial activity can improve economical productivity of the market by replacing the firms less pro-

\footnotetext{
${ }^{1}$ Technological regime (TR) is a set of the characters which is presented to distinguish different technologies compared to the process of innovation (Nelson and Winter, 1977; Dosi, 1982). Appropriability, opportunity of technology, nature of knowledge, and technological accumulation of knowledge are four dimensions of the technological regime (Breschi and Malerba 1997).
}

ductive with the more productive ones [29]. Entrepreneurship plays a crucial role in innovative activity by serving as the mechanism by which knowledge spills over from the organization producing that knowledge, to the (new) organization commercializing it [26].

Hoed [30] argues that leading firms demonstrate resistance in order to invest in radical technologies, due to organizational inertia, resource dependency in fixed assets, incorrect market appreciation, and cannibalization of their own technology, or sheer conservatism [30].

Entry in the market can motivate the increase of innovation. Aghion et al. [31] predict that the relationship between product market competition (PMC) and innovation is an inverted-U shape. It does not mean that the established firm supports entry [31]. Entry barriers and their effect on innovation is another interesting discussion for researchers. Bain [32] identified two kinds of barriers: structural and strategic. Structural entry barriers concern the market power of established firms. Strategic entry barriers arise when incumbent firms take explicit actions aimed at deterring the entry of newcomers [32]. Capital investment, switching costs, distribution access, proprietary assets, intellectual property systems, and product differentiation are the strategic entry barriers that incumbent firms can use to deter entry [28,33]. The barriers, in general, provide some protection against a new entrant but the extent of protection varies widely against entry of the innovative kind [34]. The scale of economy, opportunity conditions, the nature of knowledge and the technological life cycle are the factors that affect the efficiency of entry barriers [3,15,26]. Entry barriers increase firms' incentive to innovate by making rival behavior more stable and predictable, thereby reducing the uncertainty associated with excessive rivalry [35]. At the same time, entry barriers may reduce incentive for innovation by allowing incumbents to collude and stamp out competition [34,35].

As Shane and Venkataraman [36] did, we also consider entrepreneurial activity as a market entry in innovation competition [36]. Gans and Stern [37] argue that the technological entry of new firms and established firms is different because of access to complementary assets [37]. Robert et al. [27] argue that entrepreneurial activity, as technological entry, presents a significant challenge for larger corporations because their core competencies do not always extend into the areas of new development and management and incentive systems frequently stifle entrepreneurial initiatives [27]. Young [38], however, does not support this view. For him, historical examples of technological change suggest that new technologies may be complement to an older technology by creating rather than destroying rents [38].

\subsection{Innovation and Firm Size}

Many factors are mentioned as source of technological 
changes. These include firm size, market concentration, demand condition, technological opportunity, technological variety, appropriablity conditions, and firms' natality or persistence. The following paragraphs describe the principal finding regarding each of these factors at the industry or firm level.

\subsubsection{The Relationship between Market Structure and Innovation}

According to Schumpeterian dynamics, the large firms with large market share are the engines of innovation. We can find different arguments in the literature of Schumpeterian dynamics [39]:

- The projects of R \& D imply great fixed costs, but these costs can be covered if the sales are sufficiently large.

- There is economy of scale and scope in the production of innovations.

- The large diversified companies in better position make use of diversified inventions and innovations.

- The large companies can undertake many projects any time and consequently eliminate the risks of the $\mathrm{R} \& \mathrm{D}$.

- The large companies have better access than small companies to external finances.

- The companies with a greater market power can best cover R \& D expenditures.

These arguments formed the basis of much of research. Scherer [40] and Mowery and Rosenberg [41] observed the increase in average cost of R \& D. If the high cost of $\mathrm{R} \& \mathrm{D}$ is an obstacle for small companies, they can overcome it by participating in joint R \& D. But the studies show that they were overcome $[40,41]$. The positive effect of joint $R$ \& $D$ on the innovation success is not strong [42], because the small companies make less joint R \& D than the large ones [42,43] and if they make joint $\mathrm{R} \& \mathrm{D}$, they make it with the large companies rather than the small ones [44]. Baldwin et al. [45], by studying small Canadian firms, find that the use of debt by small firms differs from one industry to another. In the risky sectors, they prefer to use the cash flow and in the less risky industries, they look for debts. But they also find that the firms which have long term debts innovate less than the firms with short term debts [45]. Koga [46] analyzed the effect of the public subvention (for R \& D) on the private $\mathrm{R} \& \mathrm{D}$ of the companies in the high-tech sector of Japan. He found that public subvention is a complement for private $\mathrm{R} \& \mathrm{D}$ to the large firms rather than to small ones. A certain number of studies concentrated on the relationship between the input and the output of innovation and the size of the company in order to study the existence of the economy of scale and scope in the production of the innovations [46]. Tsai [47] found a relationship of the type " $U$ ” between productivity of R \&
$\mathrm{D}$ and the size of the company in the high technology sector. The productivity of R \& D at the small and large companies is larger than at the mid-size companies [47]. Acs and Audretcsh [22] discovered a negative relationship between the productivity of R \& D and the size of the company [22]. Cardinal and Opler [48] focused on the relationship of diversification and innovation. They assumed that organizational problems of diversified companies do not allow them to innovate. But they observed empirically that the diversified companies are more innovative than the others [48]. Cohen and Malerba [49] summarized the relevant theoretical references and empirical evidence in favor of the positive impact of technological diversity on innovative performance [49].

Concerning the relationship between market structure and innovation, Cohen [50] believes that the empirical findings give little support for the view that industrial concentration is an independent, significant, and important determinant of innovative behaviors [50]. Nevertheless, it has been recently argued that a paradox exists between the positive effect of industrial concentration on $\mathrm{R} \& \mathrm{D}$ expenditures and the non-positive effect of this factor on the number of many innovations [51].

\subsubsection{The Relationship between Demand Condition and Innovation}

Schmookler [52] hypothesized that the benefit realized by innovators is proportional to the size of the market in which the innovation is introduced. Therefore, more innovation would be expected in larger markets [52]. But in attempting to test the model, problems arose in regression: the variables of demand (sales in static analysis, rate of growth in dynamic sale models) measure endogenous interaction of demand and supply condition [50]. However, Antonelli and Calderini [53] find a positive effect of demand on innovation activity in the mechanical engineering sector [53] and Le Bas [54] studies the effect of demand quantity (adjusted value of the firms) on firms' R \& D expenditures. He finds that this effect is positive and strong in a short time [54]. Sutton [55], Malerba et al. [56] and Malerba and Orsenigo [57] focus on the impact of demand differentiation on innovation. They argue that in an industry with low demand differrentiation, the past marketing plays an important role and the new technological paradigm cannot be competencedestroying [55-57].

\subsubsection{The Relationship between Appropriability Conditions and Innovation}

Most of the literature on appropriability condition focuses on its effect within a single sector on the incentive for investing in innovation activity. There are typically inter-industry differences [58]. But Dosi [59] finds that inter-sectoral differences in the intensity of innovation 
are better accounted for by difference in opportunity and firm-specific capability rather than by variation in profitability.

\subsubsection{The Relationship between Advertising and Innovation}

Lunn [60] and Koeller [61] study the impact of advertising on innovation and their findings confirm the positive impact of advertising on R \& D intensity. Koeller [61] argues that advertising can increase product demand and support appropriability of innovation.

\subsubsection{The Relationship between Firm Natality and Firm Persistence in Innovation and Sectoral Innovativeness Differences}

Often this topic is dealt with through some basic questions: is creative destruction (entry of new efficient firms) more important than creative accumulation (persistence of consistent innovative firms)? Does a stable population of large innovative firms shape the scale and scope of innovative activity? How does this phenomenon interact with a firm's competition or industrial concentration? Industrial and technological turbulence seem to affect only the fringes of the industry. Technological entering and exiting firms are small, both economically (in terms of firm size) and technologically (in term of innovation) [20].

\section{French Manufacturing Firms and Destroying Creation}

According to destroying creation theory (or entrepreneurial theory), small firms are engines of radical innovations that destroy the existing competence and technological knowledge. The entry of small innovative firms introduces turbulence in the market and forces the grand number of incumbents to exit the market. Here we use the patent database of European Patent Office (EPO) and the yearly survey of French firms (EAE) to test this theory (patent numbers for the period 1993-2001 are in Appendix 5). We gather the innovation activity of French firms for periods, 1993-1996 and 1998-2001 and we adapt this database to yearly survey French firms to take the firm size data. The following tables show the entrepreneurial pattern of French manufacturing firms.

Table 1 shows the entry and exit conditions of French manufacturing firms in selected periods. Generally, 1731 firms entered the innovation activity for the first time in the 1998-2001 period (they have not patented in the period 1993-1996). They obtained in total 3929 patents in

\footnotetext{
${ }^{2}$ Ministère de l'Education National: Enquête sur les Moyens Consacrés à la Recherche et au Développement.

${ }^{3}$ EAE (Enquête Annuelle d'Entreprise) by the French Ministry of economy_SESSI (Service d'Etudes des Stratégies et des Statistiques Industrielles).
}

this period. The average of patent numbers per entrant in this period is 2.27, whereas the average of patent number for established firms in the same period is 6.91. The percentage of new patents from entrants during this period represents $16 \%$. On the other hand, 1989 firms innovated for the last time in the period 1993-1996 (they have not innovated in periods 1998-2001), and in total they obtained 4259 patents in this period. The average of patent number per incumbent in this period is 2.14 , whereas the average of patent numbers for continually innovating firms in this period is 6.35. The participation of incumbents in patent application in the period 1993-1996 is $20 \%$.

These results confirm the important role of established, continually innovative firms in the innovation pattern of French firms.

Now we concentrate on the size of entrants and incumbents.

According to Table 2, medium sized firms have an advantage in technological entry. The number of medium sized enterprises that enter in to innovation activity and their participation in patent application, is significantly more than both large and small enterprises. The number of small entrants is more than the large ones but their participation in patent application is low.

The number of incumbents in different size categories is appropriate for the number of entrants, but Table $\mathbf{3}$ shows that large incumbents are more innovative than small and medium ones before they cease innovation activity. The small incumbents are the least innovative.

Table1. Technological turbulence in France (1993-2001).

\begin{tabular}{lcc}
\hline \multicolumn{1}{c}{ Patent EPO } & entry & exit \\
\hline total number & 1731 & 1989 \\
total patent & 3929 & 4259 \\
avrerage patent per firm & 2.27 & 2.141 \\
participation in total patent & 0.161 & 0.199 \\
\hline
\end{tabular}

Table 2. Technological entry in France (1998-2001).

\begin{tabular}{cccc}
\hline & small & medium & large \\
\hline entry number & 466 & 575 & 327 \\
patent & 943 & 1376 & 690 \\
average & 2.0236 & 2.393 & 2.11 \\
\hline
\end{tabular}

Table 3. Technological exit in France (1993-1996).

\begin{tabular}{cccc}
\hline & small & medium & large \\
\hline entry number & 504 & 666 & 389 \\
patent & 967 & 1360 & 881 \\
average & 1.919 & 2.042 & 2.265 \\
\hline
\end{tabular}




\section{Empirical Specification}

The following two null hypotheses were tested:

1) The natality of firms has not an impact on innovation at the sector and firm levels.

2) The existence of large firms, which innovate persistently, is not a determinant of innovation.

\subsection{Data and Variables}

We used different databases and surveys to estimate our models. We obtained patent data from the European Patent Office (EPO) database for French firms. We adopted this database with 30 technological classes by using the patent international classification (PIC). Appendix 1 shows this classification and the adaptation. The R \& D information of this study was obtained from the yearly survey of the R \& D resources in France (MENRT) ${ }^{2}$. We gathered firm-specific data as firm's size, firm's turn over, exportation...etc. from the yearly firm's surveys $\mathrm{EAE}^{3}$ in France. All of the cited databases referred to the period 1993-2001. As noted, we aimed to understand why one firm innovates more than another, and also to understand why a given technological class innovates more than another. To achieve these goals, we created two types of variables: sectoral-specific variable and firm-specific variable. Table 4 shows the dependent and independent variables of our models.

In order to test the impact of both sector-specific and firm-specific variables on innovation, we chose two types of models in two different levels of analyses: at firm level and sectorial level. Appendix 2 shows the existence of our variables in different levels as well as time periods.

\subsection{Models}

Two null hypothesis:

Hypothesis 1: The natality of firms does not have an impact on innovation at the sector and firm levels.

Hypothesis 2: The existence of large firms which innovate persistently is not determinant to the innovation.

A possible proxy for innovation is the number of patents that the firms apply for. The basic specification to explain the relationship between patent application as indicator of innovation and Schumpeterian dynamic can be expressed through the following equation:

\subsubsection{Model at Sector Level}

$$
\begin{aligned}
& \text { Ptotclass }_{s t}=\alpha+\beta_{1} p_{-} \text {entrer }{ }_{s t}=\beta_{2} \text { herf__brev }_{s t} \\
& +\beta_{3} \text { herf_emp } p_{s t}+\beta_{4} c o r_{-} \text {spear }_{s t}+\beta_{5} C 4_{s t} \\
& +\beta_{6} N_{-} \text {entrer } r_{s t}+\beta_{7} \text { Herfcaht }_{s t}+\beta_{8} \text { Totcaht }+\varepsilon_{s t}
\end{aligned}
$$

\subsubsection{Model at Firm Level}

$$
\begin{aligned}
& \text { P } \text { class }_{\text {sit }}=\alpha+\beta_{1} p_{-} \text {entrer }_{s t}+\beta_{2} \text { herf_brev }_{s t} \\
& +\beta_{3} \text { herf_emp }{ }_{s t}+\beta_{4} \text { cor_spear }{ }_{s t}+\beta_{5} C 4_{s t} \\
& +\beta_{6} n \_ \text {entrer }{ }_{s t}+\beta_{7} \text { Herfcaht }{ }_{s t}+\beta_{8} \text { totcaht }_{s t} \\
& \left.+\beta_{9} \text { Ebcaht }{ }_{i t}+\beta_{10} \text { employ (or caht or achat }\right)_{i t} \\
& +\beta_{11} \text { Intansiterd }_{i t}+\beta_{12} \text { financepub }_{i t} \\
& +\beta_{13} \text { Diver }_{i t}+\beta_{14} \text { pub }_{i t}+\beta_{15} \text { export }_{i t}+\varepsilon_{\text {sit }}
\end{aligned}
$$

The sector-specific factors-the variables indicated by $(s t)$-are the set of sectoral variables of $s^{\text {th }}$ technological class in the period of $t$, and finally firm specific factors - the variables indicated by (it) - are the quantity of the set of firm specific variables for the $i^{\text {th }}$ firm in the period of $t$.

At the firm level, we estimate two types of models: in the first model, we have not integrated the R \& D intensity of firms; in the second model, this variable is integrated. There are two reasons for this separation:

- By integrating R \& D intensity the number of observations decreases (many firms do not have an $\mathrm{R} \& \mathrm{D}$ department);

- We consider the R \& D intensity as an intermediary variable in the relationship of patents and Schumpeterian dynamics.

\subsection{Model Evaluation by Count Data Methodology}

Innovation can be measured either by number of patents or by turn over. Patent application by firms in different technological classes is our proxy for innovation. Our main endogenous variable and the count data models are the appropriate statistical models. Hence, the Poisson model is often used to model count data. The two-parameter gamma-Poisson mixture parameterization of the negative binomial distribution is often a more adequate model for overdispersed count data.

Both Poisson and negative binomial regressions have become standard in applied research that uses count data. In parallel to development, often initiated by empirical problems, several methodological issues have been raised and solved.

In count data regression, the main focus is the effect of covariates on the frequency of an event, measured by non-negative integer values or counts. Count models, such as Poisson and negative binomial, are similar to binary models, such as probit and logit, and other limited dependent variable models, notably tobit, in that the sample space of the dependent variable has restricted support. Count data models are used in a wide range of disciplines (for an early applications and survey in economics see [62]). 
Table 4. The variables and their definition.

\begin{tabular}{|c|c|c|}
\hline Variable & Definition and their sources & Measuring \\
\hline \multicolumn{3}{|r|}{ Endogenous variables } \\
\hline Ptotclass & Innovation output of class (EPO) & $\begin{array}{l}\text { Total patent of technological class. In the Equation (1) the variable Ptotclass } \text { tst }_{\text {it }} \text { the number } \\
\text { of patents of the } s^{\text {th }} \text { technological class in period } t \text { and the sector-specific factors- the } \\
\text { independent variables-are the set of sectorial variables of } s^{\text {th }} \text { technological class in the } \\
\text { period of } t \text {. }\end{array}$ \\
\hline Patintens & innovation intensity of class (EPO) & $\begin{array}{l}\text { Total patents of technological class divided by total turn over of technological class. In the } \\
\text { Equation (2) the variable Patintens } s_{s t} \text { is the innovation intensity of } s^{\text {th }} \text { technological class. } \\
\text { Innovation intensity of the technological class can be measured by the patents number applied } \\
\text { in the technological field divided by an indicator of the sector size, here, the total turn over } \\
\text { the technological class. }\end{array}$ \\
\hline P_class & Firm innovation output (EPO) & $\begin{array}{l}\text { Number of patent applications by firms in the technological class. In the Equation (3) the } \\
\text { variable } P_{\text {c class }} \text { it is the number of patents of the } i^{\text {th }} \text { firm in the } s^{\text {th }} \text { class in period } t \text {. }\end{array}$ \\
\hline Effectrd & Firm innovation input (MENRT) & Number of R \& D employees. \\
\hline Intansiterd & Firm innovation intensity (MENRT) & R \& D intensity of firms (firm R \& D expenditure divided by firm turn over). \\
\hline \multicolumn{3}{|r|}{ Exogenous variables } \\
\hline C4 & Technological concentration (EPO) & $\begin{array}{l}\text { The share of total patent applications of the four major innovating firms in technological } \\
\text { classes. }\end{array}$ \\
\hline Cor_spear & Technological persistence (EPO) & $\begin{array}{l}\text { The spearman rank correlation coefficient of firms' patent applicable to in both period } \\
1993-1996 \text { and 1998-2001 in technological classes. }\end{array}$ \\
\hline herf_brev & Technological concentration (EPO) & Herfindahl index of the share of total patent applications by technological classes. \\
\hline P_entrer & $\begin{array}{l}\text { Technological entry } \\
\text { (EPO) }\end{array}$ & $\begin{array}{l}\text { The share of total patent application by firms patenting for the first time in the period } \\
\text { 1998-2001. }\end{array}$ \\
\hline$N \_$entrer & $\begin{array}{l}\text { Technological entry } \\
\text { (EPO) }\end{array}$ & $\begin{array}{l}\text { The number of firms patenting for the first time in the period 1998-2001 in logarithm in the } \\
\text { technological class. }\end{array}$ \\
\hline Totcaht & Demand (EAE) & Total turn over of technological class. \\
\hline Herfcaht & Market concentration (EAE) & Herfindahl index of the firms turn over in technological class. \\
\hline Diver & Technological diversity of firm (EPO) & Number of technological classes in which the firm has patented in the period 1993-2001. \\
\hline Export & Firm exportation (EAE) & Exportation of firm. \\
\hline Employ & Firm size (EAE) & Number of firm’s employees. \\
\hline Ebecaht & Firm productivity (EAE) & Rough surplus of exploitation on firm's turn over. \\
\hline Caht & Firm size (EAE) & The firm turn over. \\
\hline Achat & Firm size (EAE) & Firm's purchases of first materials. \\
\hline Financepub & Public subvention (MENRT) & Public subvention to firms’ R \& D activity. \\
\hline Pub & Advertising (EAE) & Firm's expenditures in advertising. \\
\hline
\end{tabular}

EPO: European Patent Office; EAE: “Enquête Annuelle d’Entreprise” from SESSI; MENRT: “Ministère de l’Education National de la Recherche et de la Technologie"; Patent numbers for the period 1993-2001 are in Appendix 5.

Count data models provide a framework for modeling the frequency of the event per unit time period. The benchmark model for count data is the Poisson. If the discrete random variable $\mathrm{Y}$ is Poisson distributed with parameter $\lambda$, it has density e- $\lambda \lambda y / y$ !, mean $\lambda$ and variance $\lambda$ (the Poisson imposes equality of population mean and 
variance). Very often, the sample variance is considerably greater than the sample mean. The negative binomial distribution can potentially accommodate this over dispersion. In econometric applications with count data, analysis focuses on the role of regressors $\mathrm{X}$, introduced by specifying $\lambda=\exp \left(\mathrm{X}^{\prime} \beta\right)$, where the parameter vector $\beta$ may be estimated by maximum likelihood.

Our observations are classified in 30 technological classes. As we noted, the dependant variable of this model (patent) is the patent number which is considered as a count variable. In addition, there can be some over dispersion in the data i.e. the variance of the variable can be larger than the mean because some firms can have zero patent in a year or a technological class and they can have several patents in other years or classes. This can be misspecified the Poisson specification. For this reason, we preferred the binomial negative specification in this study.

The result reported in this section relate to the literature of entrepreneurial theory, in which the economic issue is discussed in great detail.

\subsection{Results}

\subsubsection{Results at Sector Level}

Comments: The results of Table 5 show that we reject the null hypothesis. This table displays the findings of Poisson and negative binomial models which are almost the same, except for the technological concentration of the class (herf_brev). In the poisson models, the effect of this factor on patent application of technological class is not significant.

According to this table, entry of new innovative firms (n_entrer) has a positive effect on patent application of technological class, but their patent share has a negative effect. We can assume that the new entrants that have high innovation intensity destroy competence, whereas the entrants by low innovation intensity support the knowledge that has accumulated in the market. The effect of firm size (herf_emp) on sector patent application is positive and significant (see model 1 and model 4 in Table 5). The effect of market concentration is significant only in the presence of technological concentration (C4) and technological stability (cor_spear) and in this

Table 5. Patent (number of patent) and sectoral factors.

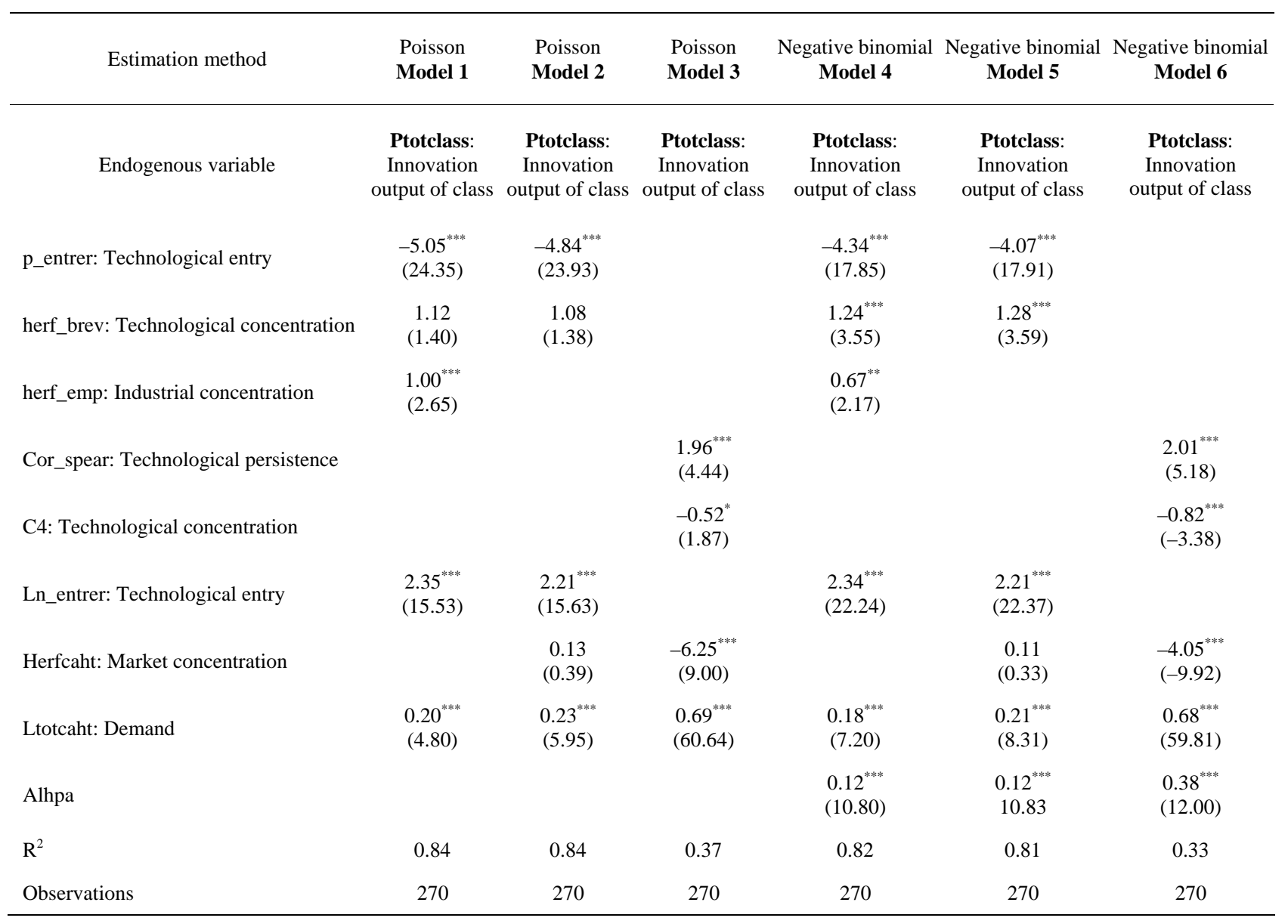

Parameters estimates are standardized with t-values shown in parentheses; ${ }^{* * *}$ Correlation is significant at the 0.01 level, ${ }^{* *}$ Correlation is significant at the 0.05 level, "Correlation is significant at the $10 \%$ level; All the variables begin with "L" are logged; Patent numbers for the period $1993-2001$ are in Appendix 5. 
case, it is negative and strong (see model 3 and model 6 in Table 5). Demand condition has a positive and significant effect on patent application of this technological field. We used turn over of technological class (Totcaht) as an indicator of demand. Whereas the technological stability (cor_spear) has a positive impact on patent application of technological class, the impact of technological concentration on patent application is negative. The impact of technological concentration can be biased by the number of firms that innovate in the class.

In all of the models in which we integrate the number of new entrant firms and their participation in the sectoral innovation, we observe that the number of new entrants has a positive effect, whereas their participation effect is negative. We assume that the entry of new innovative firms can increase the innovation intensity of sectors except when their innovations are competence-destroy ones. The effect of technological stability (cor_spear) on sectoral innovation is always negative and significant.

By this finding we should confirm the Schumpeterian pattern in which the large firms by large market power are the engine of innovation, but as the effect of market concentration (Herfcaht) on sectoral innovation is always negative, this confirmation is not reliable. The case of firm size is complex because the effect of this indicator, as the Herfidahl index of firms employ, is positive whereas the effect of this indicator, as the Herfidahl index of firms' turnover is negative. The impact of first indicator of technological concentration (the Herfidahl index of the firm's patent applications in the class) also has a non-significant impact on sectoral innovation except in the Negative Binomial models. In this case, its impact is positive. On the contrary, the effect of the second indicator of technological concentration (C4) is always negative. The demand condition (logarithm of total turn over of class) has a positive impact on innovations.

\subsubsection{Results at Firm Level}

Comments: Tables 6 and 7 show the estimations of the relationship between technological innovation and Schumpeterian dynamic. We reject the null hypothesis.

Table 6 shows the estimations without the R \& D intensity and Table 7 contains the models in which this variable is integrated. Concerning firms' specific factors, the effect of firm size (firm employees and firm turn over) on firm patent application is positive and significant (Model 1, Model 2 and Models 5-8 in Table 6). We have not put the all firm-specific variables together because of their strong correlations. The foreign ownership (exportation) has a positive and significant effect on innovation (Model 4). This is also the case for the firm purchase of first materials (Model 3). Technological diversity has a positive and significant impact on the firms' innovation. The firms' advertising has a similar impact (all models).
The impact of firm productivity is not significant. In sectoral side factors, the impact of new entry on firm innovation is complex. The number of new entrants supports the firm innovation whereas their share of patent application has a negative impact (all models).

These results are similar to the results found in the case of sectorial model. We can conclude that the new entry motivates the firms and improves their competences by external spillover except when this new entry is a result of new competence-destroy technology, in which case the participation of new entrants in sectoral patent is high. Technological concentration indicators ( $\mathrm{C} 4$ and patent herf_brev) do not have a significant effect on patent applications of firms (all models). The impact market concentration (herfcaht) and the Industrial concentration (herfemp) on patent applications of firms are positive and significant. Technological stability of technological class supports the firm innovation (models 5 and 6 in Table 6) and finally the total turn over of class as a demand indicator has a negative effect on firm innovation (all models).

In Table 7 we have integrated the R \& D intensity of firms and the public financing of the firms R \& D as independent variables. This table is not completely comparable with Table 6 because we do not have the same number of observations. In the firms-specific factor side, the effects of firm size, technological diversity, foreign ownership and firm advertising on firm innovation are positive and significant (all models). The effect of public financing (subvention for R \& D activity) on firm innovation is negative and always significant. The impact of $\mathrm{R} \& \mathrm{D}$ intensity on innovation is positive and significant, but weak (all models). In the sectoral side also the results are comparable to the results of Table 6, but there are some exceptions. In the Table 6 the effect of technological concentration ( $\mathrm{C} 4$ and herf_brev) on patent application of firms is positive and significant whereas that is not the case in Table 5.

We can compare these results with similar studies. Malerba and Orsenigo [10] study the effect of sectorspecific factors on patent applications of the sectors. They find negative effects of entry and positive effects of technological concentration on patent application of sectors. These results confirm that the concentrated sectors are more innovative than others and the turbulent sectors are less innovative than others. They also find a positive relationship between technological stability and patent applications of sectors [24].

Our results confirm the findings of recent studies [48, 63]. As we can observe in Tables 6 and 7 the technological diversity has a positive impact, which is always significant, on patent application. We can propose three hypotheses to associate the diversity and innovation [39]. The first hypothesis is that large diversified firms can 
Table 6. Patent application and Schumpeterian dynamic (without $R \& D$ intensity).

\begin{tabular}{|c|c|c|c|c|c|c|c|c|}
\hline Estimation method & $\begin{array}{l}\text { Negative } \\
\text { binomial } \\
\text { Model } 1\end{array}$ & $\begin{array}{l}\text { Negative } \\
\text { binomial } \\
\text { Model } 2\end{array}$ & $\begin{array}{l}\text { Negative } \\
\text { binomial } \\
\text { Model } 3\end{array}$ & $\begin{array}{l}\text { Negative } \\
\text { binomial } \\
\text { Model } 4\end{array}$ & $\begin{array}{l}\text { Negative } \\
\text { binomial } \\
\text { Model } 5\end{array}$ & $\begin{array}{l}\text { Negative } \\
\text { binomial } \\
\text { Model } 6\end{array}$ & $\begin{array}{l}\text { Negative } \\
\text { binomial } \\
\text { Model } 7\end{array}$ & $\begin{array}{l}\text { Negative } \\
\text { binomial } \\
\text { Model } 8\end{array}$ \\
\hline Endogenous variable & $\begin{array}{c}\text { P_class: } \\
\text { Firm } \\
\text { innovation } \\
\text { output }\end{array}$ & $\begin{array}{c}\text { P_class: } \\
\text { Firm } \\
\text { innovation } \\
\text { output }\end{array}$ & $\begin{array}{c}\text { P_class: } \\
\text { Firm } \\
\text { innovation } \\
\text { output }\end{array}$ & $\begin{array}{c}\text { P_class: } \\
\text { Firm } \\
\text { innovation } \\
\text { output }\end{array}$ & $\begin{array}{l}\text { P_class: } \\
\text { Firm } \\
\text { innovation } \\
\text { output }\end{array}$ & $\begin{array}{c}\text { P_class: } \\
\text { Firm } \\
\text { innovation } \\
\text { output }\end{array}$ & $\begin{array}{c}\text { P_class: } \\
\text { Firm } \\
\text { innovation } \\
\text { output }\end{array}$ & $\begin{array}{c}\text { P_class: } \\
\text { Firm } \\
\text { innovation } \\
\text { output }\end{array}$ \\
\hline p_entrer: Technological entry & $\begin{array}{c}-2.52^{* * *} \\
(18.91)\end{array}$ & $\begin{array}{c}-2.66^{* * *} \\
(19.94)\end{array}$ & $\begin{array}{c}-2.60^{* * *} \\
(19.5)\end{array}$ & $\begin{array}{c}-2.66^{* * *} \\
(20.00)\end{array}$ & & & $\begin{array}{c}-2.74^{* * *} \\
(19.58)\end{array}$ & $\begin{array}{c}-2.90^{* * *} \\
(20.79)\end{array}$ \\
\hline herf_brev: Technological concentration & $\begin{array}{l}-0.23 \\
(0.96)\end{array}$ & $\begin{array}{l}-0.28 \\
(1.17)\end{array}$ & $\begin{array}{l}-0.28 \\
(1.14)\end{array}$ & $\begin{array}{l}-0.12 \\
(0.50)\end{array}$ & & & $\begin{array}{l}-0.19 \\
(0.78)\end{array}$ & $\begin{array}{l}-0.23 \\
(0.96)\end{array}$ \\
\hline herf_emp: Industrial concentration & & & & & & & $\begin{array}{l}1.80^{* * *} \\
(7.08)\end{array}$ & $\begin{array}{l}1.99^{* * *} \\
(7.76)\end{array}$ \\
\hline c4: Technological concentration & & & & & $\begin{array}{l}0.056 \\
(0.55)\end{array}$ & $\begin{array}{c}0.15 \\
(1.51)\end{array}$ & & \\
\hline cor_spear: Technological persistence & & & & & $\begin{array}{l}2.33^{* * *} \\
(16.40)\end{array}$ & $\begin{array}{l}2.39^{* * *} \\
(16.77)\end{array}$ & & \\
\hline Ebcaht: Firm productivity & $\begin{array}{l}0.004 \\
(0.15)\end{array}$ & $\begin{array}{c}-0.031 \\
(0.99)\end{array}$ & $\begin{array}{c}-0.043 \\
(1.40)\end{array}$ & $\begin{array}{c}0.001 \\
(0.003)\end{array}$ & $\begin{array}{c}0.003 \\
(0.089)\end{array}$ & $\begin{array}{c}-0.032 \\
(1.00)\end{array}$ & $\begin{array}{l}0.006 \\
(0.19)\end{array}$ & $\begin{array}{l}-0.03 \\
(0.96)\end{array}$ \\
\hline Lemploy: Firm size & $\begin{array}{l}0.18^{* * * *} \\
(17.3)\end{array}$ & & & & $\begin{array}{l}0.18^{* * * *} \\
(17.60)\end{array}$ & & $\begin{array}{l}0.18^{* * * *} \\
(17.14)\end{array}$ & \\
\hline Lcaht: Firm size & & $\begin{array}{l}0.18^{* * * *} \\
(17.84)\end{array}$ & & & & $\begin{array}{l}0.18^{* * * *} \\
(17.64)\end{array}$ & & $\begin{array}{l}0.18^{* * *} \\
(17.87)\end{array}$ \\
\hline Lachat: Firm size & & & $\begin{array}{c}0.113^{* * *} \\
(16.88)\end{array}$ & & & & & \\
\hline Diver: Technological diversity & $\begin{array}{l}0.09^{* * *} \\
(41.03)\end{array}$ & $\begin{array}{l}0.09^{* * *} \\
(39.03)\end{array}$ & $\begin{array}{l}0.10^{* * *} \\
(47.11)\end{array}$ & $\begin{array}{l}0.11^{* * *} \\
(48.35)\end{array}$ & $\begin{array}{c}0.1^{* * *} \\
(42.36)\end{array}$ & $\begin{array}{l}0.10^{* * *} \\
(40.29)\end{array}$ & $\begin{array}{l}0.010^{* * *} \\
(41.30)\end{array}$ & $\begin{array}{l}0.09^{* * *} \\
(39.25)\end{array}$ \\
\hline Ln_entrer: Technological entry & $\begin{array}{l}0.28^{* * *} \\
(11.19)\end{array}$ & $\begin{array}{l}0.35^{* * *} \\
(13.48)\end{array}$ & $\begin{array}{l}0.30^{* * *} \\
(11.86)\end{array}$ & $\begin{array}{l}0.32^{* * *} \\
(12.33)\end{array}$ & $\begin{array}{l}0.30^{* * *} \\
(11.17)\end{array}$ & $\begin{array}{l}0.37^{* * *} \\
(13.65)\end{array}$ & $\begin{array}{l}0.34^{* * *} \\
(12.27)\end{array}$ & $\begin{array}{l}0.41^{* * *} \\
(14.65)\end{array}$ \\
\hline Lpub: Advertising & $\begin{array}{c}0.073^{* * *} \\
(5.74)\end{array}$ & $\begin{array}{c}0.036^{* * *} \\
(2.60)\end{array}$ & $\begin{array}{c}0.087^{* * *} \\
(7.00)\end{array}$ & $\begin{array}{c}0.102^{* * *} \\
(8.09)\end{array}$ & $\begin{array}{c}0.069^{* * *} \\
(5.40)\end{array}$ & $\begin{array}{l}0.035^{* *} \\
(2.49)\end{array}$ & $\begin{array}{c}0.074^{* * *} \\
(5.80)\end{array}$ & $\begin{array}{l}0.036^{* *} \\
(2.56)\end{array}$ \\
\hline Ltotcaht: Demand & $\begin{array}{c}-0.37^{* * *} \\
(21.71)\end{array}$ & $\begin{array}{l}-0.53^{* * *} \\
(24.69)\end{array}$ & $\begin{array}{l}-0.41^{* * * *} \\
(22.89)\end{array}$ & $\begin{array}{c}-0.35^{* * * *} \\
(20.65)\end{array}$ & $\begin{array}{c}-0.47^{* * *} \\
(23.84)\end{array}$ & $\begin{array}{l}-0.64^{* * * *} \\
(26.84)\end{array}$ & $\begin{array}{l}-0.40^{* * * *} \\
(22.40)\end{array}$ & $\begin{array}{c}-0.56^{* * * *} \\
(25.51)\end{array}$ \\
\hline Herfcaht: Market concentration & $\begin{array}{l}1.24^{* * * *} \\
(5.10)\end{array}$ & $\begin{array}{l}1.34^{* * * *} \\
(5.44)\end{array}$ & $\begin{array}{l}1.21^{* * *} \\
(4.91)\end{array}$ & $\begin{array}{l}1.30^{* * *} \\
(5.30)\end{array}$ & $\begin{array}{l}0.50^{* * *} \\
(2.16)\end{array}$ & $\begin{array}{l}0.51^{* *} \\
(2.17)\end{array}$ & & \\
\hline Lexport: Exportation & & & & $\begin{array}{l}0.058^{* * *} \\
(13.84)\end{array}$ & & & & \\
\hline $\mathrm{R}^{2}$ & 0.63 & 0.67 & 0.75 & 0.74 & 0.54 & 0.58 & 0.63 & 0.67 \\
\hline Alpha & $\begin{array}{l}4.12^{* * *} \\
(65.68)\end{array}$ & $\begin{array}{l}4.12^{* * *} \\
(65.79)\end{array}$ & $\begin{array}{l}4.13^{* * *} \\
(65.67)\end{array}$ & $\begin{array}{l}4.15^{* * *} \\
(65.69)\end{array}$ & $\begin{array}{l}4.17^{* * *} \\
(66.17)\end{array}$ & $\begin{array}{l}4.18^{* * *} \\
(66.26)\end{array}$ & $\begin{array}{l}4.12^{* * *} \\
(65.68)\end{array}$ & $\begin{array}{l}4.12^{* * *} \\
(65.78)\end{array}$ \\
\hline $\mathrm{N}$ & 49212 & 49212 & 49212 & 49212 & 49212 & 49212 & 49212 & 49212 \\
\hline
\end{tabular}

Parameters estimates are standardized with t-values shown in parentheses; ${ }^{* * *}$ Correlation is significant at the 0.01 level, ${ }^{* *}$ Correlation is significant at the 0.05 level, "Correlation is significant at the $10 \%$ level; All the variables begin with "L" are logged; Patent numbers for the period $1993-2001$ are in Appendix 5.

benefit from positive spillovers between the various research programs they undertake. The second hypothesis is that large diversified firms are in a better position to exploit unforeseen innovations. The idea here is that the results of research, especially basic research, are often unpredictable, and a diversified firm has more opportunities to exploit the new knowledge outside the product line for which the original research was done. The third hypothesis is that large firms can undertake many projects at any one time and hence spread the risks of $\mathrm{R} \& \mathrm{D}$.

The effect of foreign ownership on patent applications is complex. Some studies find a negative association of 
Table 7. Patent application and Schumpeterian dynamic (with $R \& D$ intensity integrated).

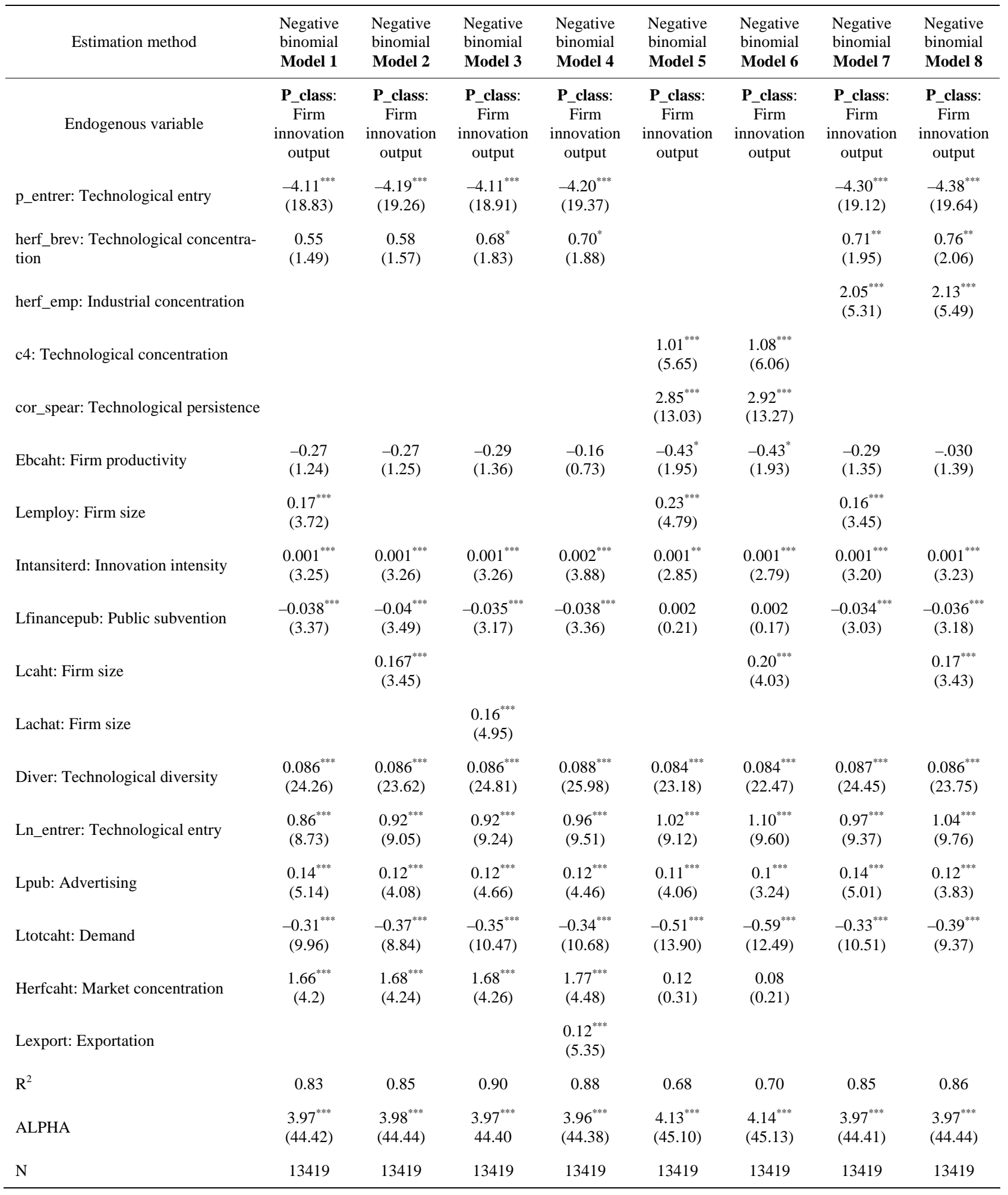

Parameters estimates are standardized with t-values shown in parentheses; ${ }^{* * *}$ Correlation is significant at the 0.01 level, ${ }^{* *}$ Correlation is significant at the 0.05 level, "Correlation is significant at the 10\% level; All the variables begin with "L” are logged; Patent numbers for the period $1993-2001$ are in Appendix 5.

exportation with innovation [64,65], and some others find a positive effect of exportation on innovation [66].
Our result confirms the finding of the last and shows the positive effect of exportation on innovation. We can as- 
sume that the firms can learn from the foreign markets by exportation and this can increase the probability of innovation.

The relationship of innovation and firm size has been discussed by many studies. To summarize the findings we can note that the effect of firm size (number of employees or firm sale) on R \& D intensity is always positive whereas the effect of this indicator on innovation output (i.e. patent) is not clear [39].

In the studies in which the researchers use a questionnaire (to construct qualitative variable for innovation) the effect of firm size on innovation is significantly positive [67,68]. Garcia-Vega [64] finds a significantly negative effect of firm size (firm sale) on R \& D intensity but a positive effect on innovation output (patent application) [63]. Our findings confirm the positive effect of firm size (number of employees and firm turn over) on patent application.

\section{Conclusions}

We have examined the Schumpeterian dynamic of innovation patterns in the firm and sectoral level. Our models contained the technological regime indicators as technological concentration, technological stability and technological entry. The classical determinants of innovation are firm size, firm diversity, and market structure, which are also integrated in these models. We have included, the factors that are recently considered intermediate in the patterns of innovation. These factors are as follows: demand conditions, firm advertising, public subvention to $\mathrm{R} \& \mathrm{D}$ activity and foreign ownership. Our results confirm the importance of technological regime in the innovation pattern on the firm and sectoral levels.

For sectoral level our findings show that the new innovative entry can support the patent application of technological class except when the entrants arrive in market by large participation in patent application. In this case, the patent application decreases. We assume that the entry of new innovative firms can increase the innovation intensity of a sector except for when their innovations are competence-destroy innovations. We should note here that the firms' formation and technological entry are conceptually different. A new entrant to our models may be a long established firm that innovates for first time. This is not an indicator for start up but instead for technological entry. As we take into account all of the technological entries, the failure of the entry may not be a problem to our models [69].

The R \& D intensity of the firm has a positive but weak impact on the patent application whereas the public subvention for R \& D activity is negative and sometimes insignificant. It can be argued that the public subvention increases the firm's motivation to do fundamental re- search, and this argument can be confirmed by the positive effect of this subvention on firms' $R$ \& $D$ expenditure.

The present study can lead to several future areas of research:

- The entrepreneurial model uses only linear model to propose the impact of technological specification and innovation dynamics. It should be reconstructed with network models.

- The entrepreneurial model should be used to analyze the technological transfer amount enterprises.

\section{REFERENCES}

[1] S. Klepper, "Entry, Exit, Growth, and Innovation over the Product Life Cycle,” Ph.D. Thesis, Carnegie Mellon University, Pittsburgh, 1993.

[2] B. Jovanovic and G. M. MacDonald, "The Life Cycle of a Competitive Industry,” Journal of Political Economy, Vol. 102, No. 2, 1994, 322-347. doi:10.1086/261934

[3] J. M. Utterback and F. F. Suàrez, "Innovation, Competition and Industry Structure,” Work Paper, Massachusetts Institute of Technology, 1990.

[4] C. Freeman, "Technology Policy and Economic Performance: Lesson from Japan,” Pinter Publishers, London, 1987.

[5] R. R. Nelson, "National Innovation Systems: A Comparative Analysis,” Oxford University Press, New York, 1993.

[6] B. Lundvall, B. Johnson, E. Anderson and B. Dalum, "National Systems of Production, Innovation and Competence Building,” Research Policy, Vol. 31, No. 2, 2002, pp. 213-231.

[7] A. Saxenian, "Inside-Out: Regional Networks and Industrial Adaptation in Silicon Valley 1994, and Rout 128,” In: C. Edquist, Ed., Systems of Innovation: Technologies, Organizations, and Institutions, Pinter Publishers, London, 2001, pp. 28-49.

[8] P. Cooke, M. G. Uranga and G. Etxebarria, "Regional Innovation Systems: Institutional and Organisational Dimensions,” Research Policy, Vol. 26, No. 4-5, 2001, pp. 475-491.

[9] M. E. Porter, "Cluster and New Economic of Competition,” Harvard Business Review, Vol. 76, No. 6, 1998, pp. 77-90.

[10] Ch. Lebas, et al., "Technological Natality, Firm Innovative Persistence, Sectoral Innovative Performance and International Technological Specialization," Commissariat Général du Plan, Vol. 10, 2003, pp. 1-20.

[11] B. Carlsson and R. Stankiewicz, "On the Nature Function and Composition of Technological Systems," Journal of Evolutionary Economics, Vol. 1, No. 2, 1991, pp. 93-118.

[12] E. Dahmen, "Developing Blocks in Industrial Economics," Scandinavian Economic History Review, Vol. 36, No. 1, 1988, pp. 3-14.

[13] B. Carlsson, S. Jacobsson, M. Holmén and A. Rickne, "Innovation Systems: Analytical and Methodological Is- 
sues,” Research Policy (Elsevier), Vol. 31, No. 2, 2002, pp. 233-245.

[14] S. Breschi and F. Malerba, "Sectoral Innovation Systems: Technological Regimes, Schumpeterian Dynamics and Spatial Boundaries,” In: G. Alfonso and F. Malerba, Eds., The Organisation of Economic Innovation in Europe, Cambridge University Press, Cambridge, 1999, pp. 88-102.

[15] F. Malerba, and L. Orsenigo, “Technological Entry, Exit and Survival: An Empirical Analysis of Patent Data," Research Policy, Vol. 28, No. 6, 1999, pp. 643-660. doi:10.1016/S0048-7333(99)00005-0

[16] D. B. Audretsch, "What's New about the New Economy? Source of Growth in the Managed and Entrepreneurial Economies," Industrial and Corporate Change, Vol. 10, No. 1, 2001, pp. 267-313. doi:10.1093/icc/10.1.267

[17] D. Pilat, "The Role of Technological Change in Recent Growth Patterns," 2001.

[18] O. Grandstrand, "Toward a Theory of the TechnologicalBased Firm,” Research Policy, Vol. 27, No. 6, 1998, pp. 465-489. doi:10.1016/S0048-7333(98)00067-5

[19] P. Geroski, J. Van Reenen and C. F. Walters, "How Persistently Do Firms Innovate?” Research Policy, Vol. 26, No. 1, 1997, pp. 33-48. doi:10.1016/S0048-7333(96)00903-1

[20] F. Malerba, L. Orsenigo and P. Peretto, "Persistence of Innovative Activities Sectoral Patterns of Innovation and International Technological Specialization,” International Journal of Industrial Organizational, Vol. 15, No. 6, 1997, pp. 801-821. doi:10.1016/S0167-7187(97)00012-X

[21] S. G. Winter, "Schumpeterian Competition in Alternative Technological Regimes,” Journal of Economic Behaviour and Organization, Vol. 5, No. 3-4, 1984, pp. 287-320. doi:10.1016/0167-2681(84)90004-0

[22] Z. J. Acs and D. B. Audretsch, "R \& D, Firm Size and Innovative Activity," In: Z. J. Acs and D. B. Audretsch, Eds., Innovation and Technological Change, An International Comparison, University of Michican Press, Ann Arbor, 1991, pp. 59-70.

[23] F. Malerba and L. Orsenigo, "Schumpeterian Pattern of Innovation,” Cambridge Journal of Economics, Vol. 19, No. 1, 1995, pp. 47-65.

[24] F. Malerba and L. Orsenigo, "Schumpeterian Patterns of Innovations Are Technology-Specific,” Research Policy, Vol. 25, No. 3, 1996, pp. 451-478. doi:10.1016/0048-7333(95)00840-3

[25] J. Teece and G. Pisano, "The Dynamic Capabilities of Firms: An Introduction,” Industrial and Corporate Change, Vol. 3, No. 3, 1994, pp. 537-556. doi:10.1093/icc/3.3.537-a

[26] Z. J. Acs and D. B. Audretsch, "Entrepreneurship, Innovation and Technological Change,” Work Paper, Institute for Development Strategies, 2005.

[27] E. Robert, R. E. Hoskisson and L. W. Busenitz, "Market Uncertainty and Learning Distance in Corporate Entrepreneurship Entry Mode Choice,” In: M. A. Hitt, R. D. Ireland, S. M. Camp and D. L. Sexton, Eds., Strategic Entrepreneurship: Creating a New Integrated Mindset, Blackwell Publishers, Oxford, 2001, pp. 80-98.
[28] P. A. Geroski, "Entry and the Rate of Innovation,” Economics of Innovation and New Technology, Vol. 1, No. 3, 1991, pp. 203-214. doi:10.1080/10438599100000002

[29] A. Martın-Marcos and J. Jaumandreu, "Entry, Exit and Productivity Growth: Spanish Manufacturing during the Eighties,” Spanish Economic Review, Vol. 6, No. 3, 2001, pp. 211-226.

[30] R. V. Hoed, “Sources of Radical Technological Innovation: The Emergence of Fuel Cell Technology in the Automotive Industry," Journal of Cleaner Production, Vol. 15, No. 11-12, 2001, pp. 1014-1021. doi:10.1016/j.jclepro.2006.05.032

[31] P. Aghion, N. Bloom, R. Blundell, R. Griffith and P. Howitt, "Competition and Innovation: An Inverted-U Relationship," The Quarterly Journal of Economics, Vol. 120, No. 2, 2005, pp. 701-728.

[32] J. S. Bain, "Barriers to New Competition: Their Character and Consequences in Manufacturing Industries,” Harvard University Press, Cambridge, 1956.

[33] C. Langinier, “Are Patents Strategic Barriers to Entry?” Journal of Economics and Business, Vol. 56, No. 5, 2004, pp. 349-361. doi:10.1016/j.jeconbus.2004.02.002

[34] J. K. Han, N. Kim and H. B. Kim, "Entry Barriers: A Dull-, One-, or Two-Edged Sword for Incumbents? Unraveling the Paradox from a Contingency Perspective," Journal of Marketing, Vol. 65, No. 1, 2001, pp. 1-14. doi:10.1509/jmkg.65.1.1.18133

[35] I. P. Mahmood and C. Y. Lee, "Business Groups: Entry Barrier-Innovation Debate Revisited," Journal of Economic Behavior \& Organization, Vol. 54, No. 4, 2004, pp. 513-531.

[36] S. Shane and S. Venkataraman, "The Promise of EntrePreneurship as a Field of Research,” Academy of Management Review, Vol. 25, No. 1, 2002, pp. 217-221. doi: $10.2307 / 259271$

[37] J. S. Gans and S. Stern, "The Product Market and the Market for Ideas: Commercialization Strategies for Technology Entrepreneurs,” Research Policy, Vol. 32, No. 2, 2003, pp. 333-350. doi:10.1016/S0048-7333(02)00103-8

[38] A. Young, "Substitution and Complementarity in Endogenous Innovation,” The Quarterly Journal of Economics, Vol. 108, No. 3, 1993, pp. 775-807. doi: $10.2307 / 2118408$

[39] G. Symeonidis, "Innovation, Firm Size and Market Structure: Schumpeterian Hypothesis and Some New Themes," Working Papers, OECD Economic Department, 1996.

[40] F. M. Scherer, "Changing Perspectives on the Firm Size Problem,” In: Z. J. Acs and D. B. Audretsch, Eds., Innovation and Technological Change, University of Michican Press, Ann Arbor, 1991.

[41] D. C. Mowery and N. Rosenberg, "Technology and the Pursuit of Economic Growth,” Cambridge University Press, Cambridge, 1989. doi:10.1017/CBO9780511664441

[42] S. Negassi, "R \& D Co-Operation and Innovation a Microeconometric Study on French Firms,” Research Policy, Vol. 33, No. 3, 2004, pp. 365-384. doi:10.1016/j.respol.2003.09.010

[43] M. G. Colombo, "Firm Size and Cooperation: The Deter- 
Minants of Cooperative Agreements in Information Technology Industries," International Journal of the Economics and Business, Vol. 2, No. 1, 1995, pp. 3-29.

[44] M. Dogson, “Technological Collaboration in Industry,” Routledge, London, 1993.

[45] J. R. Baldwin, G. Galletly and V. Gaudreault, "Financing Innovation in New Small Firm: New Evidence from Canada,” Statistics Canada, Ottawa, 2002.

[46] T. Koga, "R \& D Subsidy and Self-Financed R \& D: The Case of Japanese High Technology Start-Up,” Small Business Economics, Vol. 24, No. 1, 2005, pp. 53-62. doi:10.1007/s11187-005-3096-z

[47] K. H. Tsai, "R \& D Productivity and Firm Size: A Nonlinear Examination,” Technovation, Vol. 25, No. 7, 2005, pp. 795-803. doi:10.1016/j.technovation.2003.12.004

[48] L. B. Cardinal and T. C. Opler, "Corporate Diversification and Innovative Efficiency: An Empirical Study," Journal of Accounting and Economic, Vol. 19, No. 2-3, 199, pp. 365-381. doi:10.1016/0165-4101(94)00388-L

[49] W. Cohen and F. Malerba, "Is the Tendency to Variation a Chief Cause of Progress?” Industrial and Corporate Change, Vol. 10, No. 3, 2001, pp. 387-608.

[50] W. Cohen, "Empirical Studies of Innovating Activities," In: P. Stoneman, Ed., Handbook of the Economic of Innovation and New Technology, Blackwell, Oxford, 1995.

[51] R. W. Vesson, "Market Power, Industrial Concentration and Innovative Activity," Review of Industrial Organization, Vol. 15, No. 4, 1999, pp. 367-378. doi:10.1023/A:1007727815408

[52] J. Schmookler, "Invention and Economic Growth," Harvard University Press, Cambridge, 1996.

[53] C. Antonelli and M. Calderini, "The Dynamic of Localized Technological Change,” Economics of Innovation and New Technology, Vol. 6, No. 2-3, 1999, pp. 97-120.

[54] Ch. Le Bas, "Demand Growth as Determinant of R \& D Expenditures: A Quantitative Study at the Sectoral Level," Revue d'Économie Industrielle, Vol. 105, 2003, pp. 11-22.

[55] J. Sutton, "Schumpeter Lectures: Technology and Market Structure,” European Economic Review, Vol. 40, No. 3-5, 1996, pp. 511-530. doi:10.1016/0014-2921(95)00065-8

[56] F. Malerba, R. Nelson, L. Orsenigo and S. Winter, "Demand, Innovation and the Dynamic of Market Structure: A Role of Experimental Users and Divers Preference," The 8th Schumpeter Society Conference, Manchester, June 28-2 July 2000, pp. 1-30.

[57] F. Malerba and L. Orsenigo, "Innovation and Market Structure in the Dynamics of the Pharmaceutical Industry and Biotechnology: Towards a History-Friendly Model," Industrial and Corporate Change, Vol. 11, No. 4, 2002, pp. 667-703.

[58] R. Levin, A. K. Klevorick, R. R. Nelson and S. G. R. Winter "Appropriating the Return from Industrial Research and Development," Brookings Papers on Economic Activity, Vol. 1987, No. 3, 1987, pp. 783-831. doi:10.2307/2534454

[59] G. Dosi, “Technical Change and Industrial Transformation,” Macmillan Press, London, 1997.

[60] J. Lunn, “An Empirical Analyse of Product and Process Pa- tenting: A Simulation Equation Framework,” Journal of Industrial Economics, Vol. 34, No. 3, 1986, pp. 319330. doi:10.2307/2098574

[61] C. T. Koeller, "Innovation, Market Structure and Firm Size: A Simulation Equation Model," Managerial and Decision Economics, Vol. 16, No. 3, 1995, pp. 259-269. doi:10.1002/mde.4090160308

[62] R. Winkelmann and K. F. Zimmermann, "Recent Developments in Count Data Modelling: Theory and Application," Journal of Economic Surveys, Vol. 9, No. 1, 1995, pp. 1-24. doi:10.1111/j.1467-6419.1995.tb00108.x

[63] M. Garcia-Vega, “Does Technological Diversification Promote Innovation? An Empirical Analysis for European Firms,” Research Policy, Vol. 35, No. 2, 2006, pp. 230246. doi:10.1016/j.respol.2005.09.006

[64] J. Love and S. Roper, "The Determinants of Innovation: R \& D, Technology Transfer and Networking Effect," Review of Industrial Organization, Vol. 15, No. 1, 1999, pp. 43-64. doi:10.1023/A:1007757110963

[65] R. Drago and M. Wooden, "Union, Innovation and Investment: Australian Evidence,” Applied Economics, Vol. 26, No. 6, 1994, pp. 609-615. doi:10.1080/00036849400000031

[66] M. Bhattacharya “Determinants of Innovation," Small Business Economics, Vol. 22, No. 2, 2004, pp. 155-162. doi:10.1023/B:SBEJ.0000014453.94445.de

[67] D. A. Aranda, B. M. Rata and A. R. Duarte "Innovation and Firm Size: An Empirical Study for Spanish Engineering Consulting Companies," European Journal of Innovation Management, Vol. 4, No. 3, 2001, pp. 133141. doi:10.1108/EUM0000000005671

[68] M. Rogers, "Network, Firm Size and Innovation,” Small Business Economics, Vol. 22, No. 2, 2004, pp. 141-153. doi:10.1023/B:SBEJ.0000014451.99047.69

[69] S. Shane, "Technology Regimes and New Firm Formation,” Management Science, Vol. 47, No. 9, 2001, pp. 1173-1190. doi:10.1287/mnsc.47.9.1173.9785 


\section{Appendix 1: The Technological Classes and Patent International Classification}

\begin{tabular}{|c|c|c|}
\hline & Technological classes & International Patent Classification (IPC) $^{1}$ \\
\hline \multicolumn{2}{|r|}{ Electronic-electricity } & \\
\hline 1 & Electronic composant & F21; G05F; H01B, C, F, G, H, J, K, M, R, T; H02; H05B, C, F, K \\
\hline 2 & Audiovisuel & G09F, G; G11B; H03F, G, J; H04N, R, S \\
\hline 3 & Telecomunication & G08C; H01P, Q; H03B, C, D, H, K, L, M; H04B, H, J, K, L, M, Q \\
\hline \multirow[t]{2}{*}{5} & Semi-conductor & H01L; B81 \\
\hline & Instrumentation & \\
\hline 6 & Optique & G02; G03B, C, D, F, G, H; H01S \\
\hline 7 & Analyse-measure of control & G01B, C, D, F, G, H, J, K, L, M, N, P, R, S, V, W; G04; G05B, D; G07; G08B, G; G09B, C, D; G12 \\
\hline 8 & Medical engineering & A61B, C, D, F, G, H, J, L, M, N \\
\hline \multirow[t]{2}{*}{9} & Nuclear technic & G01T; G21; H05G, H \\
\hline & Chemistry material & \\
\hline 10 & Organic chemistry & C07C, D, F, H, J, K \\
\hline 11 & Macromolecular chemistry & C08B, F, G, H, K, L; C09D, J \\
\hline 12 & Basical chemistry & A01N; C05; C07B; C08C; C09B, C, F, G, H, K; C10B, C, F, G, H, J, K, L, M; C11B, C, D \\
\hline 13 & Surfaces treatment & B05C, D; B32; C23; C25; C30 \\
\hline 14 & Metalurgy material & C01; C03C; C04; C21; C22; B22; B82 \\
\hline & pharmacy biotechnologies & \\
\hline 15 & Biotechnologies & C07G; C12M, N, P, Q, S \\
\hline \multirow[t]{2}{*}{17} & Food and agricultural products & A01H; A21D; A23B, C, D, F, G, J, K, L; C12C, F, G, H, J; C13D, F, J, K \\
\hline & Industrial processes & \\
\hline 18 & Technical processes & B01; B02C; B03; B04; B05B; B06; B07; B08; F25J; F26 \\
\hline 19 & Handling-imprimery & B25J; B41; B65B, C, D, F, G, H; B66; B67 \\
\hline 20 & Food industry and machine agriculture & A01B, C, D, F, G, J, K, L, M; A21B, C; A22; A23N, P; B02B; C12L; C13C, G, H \\
\hline 21 & Work materials & $\begin{array}{l}\text { A41H; A43D; A46D; B28; B29; B31; C03B; C08J; C14; D01; D02; D03; D04 B, C, G, H; D06 B, C, G, } \\
\text { H, J, L, M, P, Q; D21 }\end{array}$ \\
\hline \multirow[t]{2}{*}{22} & Environment-pollution & A62D; B09; C02; F01N; F23G, J \\
\hline & Machinery-mecanical-transport & \\
\hline 23 & Machine tools & B21; B23; B24; B26D, F; B27; B30 \\
\hline 24 & Engine-pump-turbines & F01 (except F01N); F02; F03; F04; F23R \\
\hline 25 & Termiques processes & F22; F23B, C, D, H, K, L, M, N, Q ; F24; F25B, C; F27; F28 \\
\hline 26 & Mechanics component & F15; F16; F17; G05G \\
\hline 27 & Transports & B60; B61; B62; B63B, C, H, J; B64B, C, D, F \\
\hline \multirow[t]{2}{*}{28} & Aircraft, aviation, weapon & B63G; B64G; C06; F41; F42 \\
\hline & Construction & \\
\hline 29 & Personnal or domestic articles & $\begin{array}{l}\text { A24; A41B, C, D, F, G; A42; A43B, C; A44; A45; A46B; A47; A62B, C; A63; B25B, C, D, F, G, H; } \\
\text { B26B; B42; B43; B44; B68; D04D; D06F, N; D07; F25D; G10B, C, D, F, G, H, K }\end{array}$ \\
\hline 30 & Construction & E01; E02; E03; E04; E05; E06; E21 \\
\hline
\end{tabular}

${ }^{1}$ For more information on IPC see: http://www.wipo.int/classifications/fulltext/new_ipc/ipcen.html. 
Appendix 2: The Existence of Variables in Different Levels and Time Period

\begin{tabular}{|c|c|c|c|c|}
\hline & Variable & In firm level & In sector level & Variation in time period \\
\hline 1 & Ptotclass & no & yes & yes \\
\hline 2 & Patintens & no & yes & yes \\
\hline 3 & P_class & yes & No & yes \\
\hline 4 & $R d$ & yes & No & yes \\
\hline 5 & Effectrd & yes & No & yes \\
\hline 6 & Intansiterd & yes & No & yes \\
\hline 7 & $c 4$ & no & yes & yes \\
\hline 8 & cor_spear & no & yes & no \\
\hline 9 & herf_brev & no & yes & yes \\
\hline 10 & herf_emp & no & yes & yes \\
\hline 11 & p_entrer & no & yes & no \\
\hline 12 & n_entrer & no & yes & no \\
\hline 13 & Totcaht & no & yes & yes \\
\hline 14 & Herfcaht & no & yes & yes \\
\hline 15 & Diver & yes & No & no \\
\hline 16 & Export & yes & No & yes \\
\hline 17 & Employ & yes & No & yes \\
\hline 18 & Ebecaht & yes & No & yes \\
\hline 19 & Caht & yes & No & yes \\
\hline 20 & Achat & yes & No & yes \\
\hline 21 & Financepub & yes & No & yes \\
\hline 22 & Pub & yes & No & yes \\
\hline
\end{tabular}

\section{Appendix 3: Descriptif Statistics}

Table A. The variables at sector levels*.

\begin{tabular}{ccccc}
\hline Variables & Mean & Std Dev & Variance & Skewness \\
\hline Totcaht & $6.56502 \mathrm{E}+08$ & $4.00304 \mathrm{E}+08$ & $1.60243 \mathrm{E}+17$ & 0.0044965 \\
p_entrer & 0.29103 & 0.11808 & 0.013942 & 0.29867 \\
ptotclass & $\mathbf{1 9 0 . 5 5 5 5 6}$ & $\mathbf{1 6 2 . 9 3 5 8 1}$ & $\mathbf{2 6 5 4 8 . 0 7 6 8 3}$ & $\mathbf{1 . 7 5 4 7 8}$ \\
Patintens & $\mathbf{0 . 0 0 0 6 1 6 9 9}$ & $\mathbf{0 . 0 0 1 1 9 5 7}$ & $\mathbf{1 . 4 2 9 7 5 D} \mathbf{0 6}$ & $\mathbf{5 . 8 2 8 2 3}$ \\
herf_brev & 0.089442 & 0.079181 & 0.0062697 & 1.81860 \\
herfemp & 0.12952 & 0.10893 & 0.011866 & 1.98135 \\
n_entrer & 108.50000 & 88.11815 & 7764.80855 & 1.20380 \\
C4 & 0.42974 & 0.094697 & 0.033014 & 0.30907 \\
cor_spear & 0.027263 & 0.11850 & 0.014042 & 0.22244 \\
Herfcaht & 0.13696 & 0.092344 & 0.0085274 & 1.60094 \\
\hline
\end{tabular}

*Number of Observations: 270.

Table B. The variables at firm levels (firms without $R \& D$ expenditure). The variables parameters in firm levels (database* without the $\mathbf{R} \& \mathbf{D}$ expenditure).

\begin{tabular}{cccc}
\hline Variables & Mean & Std Dev & Variance \\
\hline P_classse & $\mathbf{0 . 7 1 8 8 5}$ & $\mathbf{4 . 1 2 7 6 0}$ & $\mathbf{1 7 . 0 3 7 0 4}$ \\
totcaht & $8.04249 \mathrm{E}+08$ & $4.10598 \mathrm{E}+08$ & $1.68591 \mathrm{E}+17$ \\
\hline
\end{tabular}




\section{Continued}

\begin{tabular}{ccccc}
\hline export & 1047158.27940 & 6657420.41960 & $4.43212 \mathrm{E}+13$ & 13.00234 \\
caht & 3063659.60753 & $1.67027 \mathrm{E}+07$ & $2.78980 \mathrm{E}+14$ & 8.94779 \\
achat & 1150387.99145 & 7726240.39311 & $5.96948 \mathrm{E}+13$ & 11.72924 \\
diver & 5.16136 & 5.81380 & 33.80030 & 2.14136 \\
p_entrer & 0.31002 & 0.10642 & 0.011325 & -0.11166 \\
herf_brev & 0.055397 & 0.057250 & 0.0032775 & 3.03523 \\
herf_emp & 0.084848 & 0.065896 & 0.0043423 & 3.53571 \\
ebecaht & 0.070178 & 0.36185 & 0.13093 & -51.26369 \\
employ & 1632.29859 & 8381.10265 & $7.02429 \mathrm{E}+07$ & 11.61952 \\
n_entrer & 176.81986 & 100.19148 & 10038.33338 & 0.33049 \\
pub & 33922.39159 & 239176.43016 & $5.72054 \mathrm{E}+10$ & 12.01093 \\
C4 & 0.33678 & 0.15817 & 0.025017 & 1.11781 \\
cor_spear & 0.0010591 & 0.098938 & 0.0097887 & 0.69690 \\
herfcaht & 0.098673 & 0.062100 & 0.0038564 & 2.86650 \\
\hline
\end{tabular}

*Number of Observations: 49212.

Table C. The variables at firm levels* (firms with $R$ \& D expenditure).

\begin{tabular}{ccccc}
\hline Variables & Mean & Std Dev & Variance & Skewness \\
\hline P_classse & $\mathbf{1 . 4 4 1 1 7}$ & $\mathbf{6 . 6 6 2 0 4}$ & $\mathbf{4 4 . 3 8 2 7 9}$ & $\mathbf{1 6 . 5 1 3 9 9}$ \\
Rd & $\mathbf{4 3 7 1 2 7 . 8 8 1 6 3}$ & $\mathbf{1 0 3 4 3 1 4 . 5 8 9 1 1}$ & $\mathbf{1 . 0 6 9 8 1 E + 1 2}$ & $\mathbf{3 . 7 9 4 2 7}$ \\
intansiterd & 2.85146 & 42.08562 & 1771.19901 & 21.14751 \\
totcaht & $7.66844 \mathrm{E}+08$ & $4.14604 \mathrm{E}+08$ & $1.71897 \mathrm{E}+17$ & -0.35121 \\
export & 2861654.46307 & $1.12275 \mathrm{E}+07$ & $1.26057 \mathrm{E}+14$ & 8.30537 \\
caht & 9085162.18839 & $2.94559 \mathrm{E}+07$ & $8.67650 \mathrm{E}+14$ & 5.04555 \\
achat & 3046907.64863 & $1.26206 \mathrm{E}+07$ & $1.59280 \mathrm{E}+14$ & 7.36314 \\
diver & 9.79834 & 7.55677 & 57.10477 & 0.90962 \\
P_entrer & 0.28766 & 0.10901 & 0.011884 & 0.23659 \\
herf_brev & 0.068340 & 0.067696 & 0.0045828 & 2.47408 \\
herf_emp & 0.091247 & 0.070494 & 0.0049694 & 3.31354 \\
ebecaht & 0.083712 & 0.10143 & 0.010289 & -1.24622 \\
employ & 4712.06863 & 15355.51484 & $2.35792 \mathrm{E}+08$ & 6.39451 \\
financepub & 56533.56205 & 257381.77954 & $6.62454 \mathrm{E}+10$ & 6.78543 \\
n_entrer & 142.29779 & 90.62216 & 8212.37577 & 0.64922 \\
lpub & 3.61288 & 1.13527 & 1.28883 & -0.15526 \\
C4 & 0.37322 & 0.16932 & 0.028669 & 0.81813 \\
cor_spear & 0.024412 & 0.10759 & 0.011576 & 0.34960 \\
herfcaht & 0.10439 & 0.067103 & 0.0045028 & 2.73318 \\
\hline
\end{tabular}

*Number of Observations: 13419.

Table D. The characteristics of technological classes in 2001.

\begin{tabular}{|c|c|c|c|c|c|c|}
\hline & Class & $\begin{array}{l}\text { Number of new entries } \\
\text { (Natatlity) by class in the } \\
\text { periode of 1998-2001 }\end{array}$ & $\begin{array}{l}\text { Total of patent } \\
\text { by class in } 2001\end{array}$ & $\begin{array}{l}\text { Total turn over } \\
\text { (in } 10^{3} \text { of euro) }\end{array}$ & $\begin{array}{l}\text { R \& D expenditures by } \\
\text { technological class (in } \\
\text { thasound of euros) }\end{array}$ & $\begin{array}{c}\text { Number of firms } \\
\text { which obtain patent } \\
\text { authorization in } 2001\end{array}$ \\
\hline 1 & Electronic composant & 149 & 483 & 171540904 & 6593989.11 & 266 \\
\hline 2 & Audiovisuel & 63 & 134 & 108070512 & 5717575.39 & 84 \\
\hline
\end{tabular}




\section{Continued}

\begin{tabular}{|c|c|c|c|c|c|c|}
\hline 3 & Telecomunication & 55 & 360 & 142390420 & 6551175.45 & 92 \\
\hline 4 & Informatic & 70 & 300 & 177837451 & 7715745.49 & 88 \\
\hline 5 & Semi-conductor & 19 & 104 & 78401941 & 4276565.66 & 47 \\
\hline 6 & Optique & 43 & 75 & 123801011 & 4300096.5 & 74 \\
\hline 7 & Analyse-measure of control & 189 & 286 & 249328169 & 9352619.77 & 340 \\
\hline 8 & Medical engineering & 120 & 182 & 115177292 & 5012417.52 & 172 \\
\hline 9 & Nuclear technic & 18 & 32 & 54595444 & 2840714.29 & 39 \\
\hline 10 & Organic chemistry & 36 & 112 & 147392720 & 4218924.06 & 59 \\
\hline 11 & Macromolecular chemistry & 41 & 108 & 159773495 & 4593106.1 & 76 \\
\hline 12 & Basical chemistry & 53 & 65 & 114815514 & 3312044.58 & 93 \\
\hline 13 & Surfaces treatment & 87 & 73 & 181984854 & 6662989.93 & 143 \\
\hline 14 & Metalurgy material & 66 & 110 & 186477802 & 4773153.07 & 133 \\
\hline 15 & Biotechnologies & 26 & 21 & 55007597 & 1174576.19 & 32 \\
\hline 16 & Pharmacy-cosmetic & 47 & 410 & 40705159 & 2020587.63 & 83 \\
\hline 17 & Food and agricultural products & 40 & 33 & 63839781 & 1190882.47 & 56 \\
\hline 18 & Technical processes & 164 & 276 & 219266101 & 6959468.09 & 259 \\
\hline 19 & Handling-imprimery & 292 & 265 & 206578647 & 5871032.79 & 484 \\
\hline 20 & Food industry and machine agriculture & 112 & 83 & 85210760 & 2800115.33 & 173 \\
\hline 21 & Work materials & 200 & 204 & 230684259 & 8323499.97 & 317 \\
\hline 22 & Environment-pollution & 38 & 74 & 188170504 & 3591045.34 & 66 \\
\hline 23 & Machine tools & 174 & 162 & 170104242 & 7942255.39 & 304 \\
\hline 24 & Engine-pump-turbines & 58 & 205 & 194046251 & 5480341.46 & 172 \\
\hline 25 & Termiques processes & 76 & 96 & 170266941 & 5039153.05 & 123 \\
\hline 26 & Mechanics component & 174 & 336 & 208291075 & 7856430.56 & 322 \\
\hline 27 & Transports & 183 & 864 & 233729114 & 7316931.61 & 323 \\
\hline 28 & Aircraft, aviation, weapon & 26 & 41 & 56074883 & 4157729.98 & 46 \\
\hline 29 & Personnal or domestic articles & 363 & 458 & 226930851 & 7846094.29 & 572 \\
\hline 30 & Construction & 273 & 254 & 201399229 & 5123739.77 & 430 \\
\hline
\end{tabular}

\section{Appendix 4: R \& D Employment and Schumpeterian Dynamic}

\begin{tabular}{|c|c|c|c|c|c|c|c|c|}
\hline Estimation method & $\begin{array}{c}\text { GLS } \\
\text { Model } 1\end{array}$ & $\begin{array}{c}\text { GLS } \\
\text { Model } 2\end{array}$ & $\begin{array}{c}\text { GLS } \\
\text { Model } 3\end{array}$ & $\begin{array}{c}\text { GLS } \\
\text { Model } 4\end{array}$ & $\begin{array}{c}\text { GLS } \\
\text { Model } 5\end{array}$ & $\begin{array}{c}\text { GLS } \\
\text { Model } 6\end{array}$ & $\begin{array}{c}\text { GLS } \\
\text { Model } 7\end{array}$ & $\begin{array}{c}\text { GLS } \\
\text { Model } 8\end{array}$ \\
\hline Endogenous variable & $\begin{array}{l}\text { Leffectrd: } \\
\text { Firm } \\
\text { innovation } \\
\text { input }\end{array}$ & $\begin{array}{l}\text { Leffectrd: } \\
\text { Firm } \\
\text { innovation } \\
\text { input }\end{array}$ & $\begin{array}{l}\text { Leffectrd: } \\
\text { Firm } \\
\text { innovation } \\
\text { input }\end{array}$ & $\begin{array}{l}\text { Leffectrd: } \\
\text { Firm } \\
\text { innovation } \\
\text { input }\end{array}$ & $\begin{array}{l}\text { Leffectrd: } \\
\text { Firm } \\
\text { innovation } \\
\text { input }\end{array}$ & $\begin{array}{l}\text { Leffectrd: } \\
\text { Firm } \\
\text { innovation } \\
\text { input }\end{array}$ & $\begin{array}{l}\text { Leffectrd: } \\
\text { Firm } \\
\text { innovation } \\
\text { input }\end{array}$ & $\begin{array}{l}\text { Leffectrd: } \\
\text { Firm } \\
\text { innovation } \\
\text { input }\end{array}$ \\
\hline p_entrer: Technological entry & $\begin{array}{l}-0.396^{* * *} \\
(-10.399)\end{array}$ & $\begin{array}{l}-0.464^{* * *} \\
(-12.061)\end{array}$ & $\begin{array}{l}-0.442^{* * *} \\
(-11.325)\end{array}$ & $\begin{array}{l}-0.45^{* * *} \\
(-11.25)\end{array}$ & & & $\begin{array}{c}-0.323^{* * * *} \\
(-8.148)\end{array}$ & $\begin{array}{l}-0.41^{* * *} \\
(-10.25)\end{array}$ \\
\hline herf_brev: Technological concentration & $\begin{array}{l}-0.328^{* * *} \\
(-4.339)\end{array}$ & $\begin{array}{l}-0.365^{* * *} \\
(-4.785)\end{array}$ & $\begin{array}{c}-0.349^{* * *} \\
(-4.516)\end{array}$ & $\begin{array}{c}-0.334^{* * *} \\
(-4.205)\end{array}$ & & & $\begin{array}{c}-0.361^{* * *} \\
(-4.786)\end{array}$ & $\begin{array}{c}-0.389^{* * *} \\
(-5.105)\end{array}$ \\
\hline herf_emp: Industrial concentration & & & & & & & $\begin{array}{c}-0.242^{* * *} \\
(-3.481)\end{array}$ & $\begin{array}{l}-0.19^{* * *} \\
(-2.705)\end{array}$ \\
\hline c4: Technological concentration & & & & & $\begin{array}{c}0.078^{* *} \\
(2.53)\end{array}$ & $\begin{array}{l}0.122^{* * *} \\
(3.955)\end{array}$ & & \\
\hline cor_spear: Technological persistence & & & & & $\begin{array}{l}0.124^{* * *} \\
(3.393)\end{array}$ & $\begin{array}{l}0.16^{* * *} \\
(4.319)\end{array}$ & & \\
\hline
\end{tabular}




\section{Continued}

\begin{tabular}{|c|c|c|c|c|c|c|c|c|}
\hline Ebcaht: Firm productivity & $\begin{array}{l}-0.503^{* * *} \\
(-14.314)\end{array}$ & $\begin{array}{l}-0.507^{* * *} \\
(-14.258)\end{array}$ & $\begin{array}{l}-0.426^{* * *} \\
(-11.848)\end{array}$ & $\begin{array}{l}-0.394^{* * *} \\
(-10.678)\end{array}$ & $\begin{array}{l}-0.508^{* * *} \\
(-14.397)\end{array}$ & $\begin{array}{l}-0.511^{* * *} \\
(-14.336)\end{array}$ & $\begin{array}{c}-0.497^{* * *} \\
(-14.12)\end{array}$ & $\begin{array}{l}-0.501^{* * *} \\
(-14.108)\end{array}$ \\
\hline Lemploy: Firm size & $\begin{array}{l}0.312^{* * * *} \\
(39.794)\end{array}$ & & & & $\begin{array}{l}0.311^{* * * *} \\
(39.629)\end{array}$ & & $\begin{array}{l}0.311^{* * * *} \\
(39.774)\end{array}$ & \\
\hline Lfinancepub: Public subvention & $\begin{array}{l}0.107^{* * *} \\
(53.949)\end{array}$ & $\begin{array}{l}0.105^{* * *} \\
(52.309)\end{array}$ & $\begin{array}{l}0.114^{* * *} \\
(56.303)\end{array}$ & $\begin{array}{l}0.111^{* * *} \\
(53.179)\end{array}$ & $\begin{array}{l}0.109^{* * * *} \\
(55.16)\end{array}$ & $\begin{array}{l}0.108^{* * *} \\
(53.643)\end{array}$ & $\begin{array}{l}0.107^{* * *} \\
(54.141)\end{array}$ & $\begin{array}{l}0.105^{* * *} \\
(52.464)\end{array}$ \\
\hline Lcaht: Firm size & & $\begin{array}{l}0.284^{* * *} \\
(35.99)\end{array}$ & & & & $\begin{array}{l}0.281^{* * *} \\
(35.49)\end{array}$ & & $\begin{array}{l}0.283^{* * *} \\
(35.934)\end{array}$ \\
\hline Lachat: Firm size & & & $\begin{array}{c}0.17^{* * *} \\
(29.896)\end{array}$ & & & & & \\
\hline Diver: Technological diversity & $\begin{array}{l}0.043^{* * *} \\
(67.633)\end{array}$ & $\begin{array}{c}0.043^{* * *} \\
(66.449)\end{array}$ & $\begin{array}{l}0.046^{* * *} \\
(73.093)\end{array}$ & $\begin{array}{l}0.05^{* * *} \\
(79.21)\end{array}$ & $\begin{array}{l}0.043^{* * *} \\
(67.703)\end{array}$ & $\begin{array}{l}0.043^{* * *} \\
(66.603)\end{array}$ & $\begin{array}{l}0.043^{* * *} \\
(67.819)\end{array}$ & $\begin{array}{l}0.043^{* * *} \\
(66.592)\end{array}$ \\
\hline Ln_entrer: Technological entry & $\begin{array}{l}0.085^{* * * *} \\
(4.808)\end{array}$ & $\begin{array}{l}0.137^{* * *} \\
(7.604)\end{array}$ & $\begin{array}{l}0.095^{* * * *} \\
(5.254)\end{array}$ & $\begin{array}{l}0.081^{* * *} \\
(4.363)\end{array}$ & $\begin{array}{l}0.115^{* * *} \\
(6.905)\end{array}$ & $\begin{array}{l}0.191^{* * *} \\
(11.256)\end{array}$ & $\begin{array}{c}0.028 \\
(1.501)\end{array}$ & $\begin{array}{l}0.095^{* * *} \\
(5.033)\end{array}$ \\
\hline Lpub: Advertising & $\begin{array}{l}0.074^{* * *} \\
(15.339)\end{array}$ & $\begin{array}{l}0.049^{* * *} \\
(8.948)\end{array}$ & $\begin{array}{l}0.098^{* * *} \\
(20.048)\end{array}$ & $\begin{array}{l}0.142^{* * *} \\
(29.111)\end{array}$ & $\begin{array}{l}0.069^{* * *} \\
(14.474)\end{array}$ & $\begin{array}{l}0.045^{* * *} \\
(8.227)\end{array}$ & $\begin{array}{l}0.075^{* * *} \\
(15.534)\end{array}$ & $\begin{array}{l}0.05^{* * *} \\
(9.108)\end{array}$ \\
\hline Ltotcaht: Demand & $\begin{array}{l}-0.305^{* * *} \\
(-28.258)\end{array}$ & $\begin{array}{l}-0.403^{* * *} \\
-34.032\end{array}$ & $\begin{array}{l}-0.337^{* * *} \\
(-29.246)\end{array}$ & $\begin{array}{l}-0.286^{* * *} \\
(-23.853)\end{array}$ & $\begin{array}{l}-0.298^{* * * *} \\
(-28.161)\end{array}$ & $\begin{array}{l}-0.39^{* * * *} \\
(-33.55)\end{array}$ & $\begin{array}{l}-0.312^{* * *} \\
(-29.168)\end{array}$ & $\begin{array}{c}-0.407^{* * *} \\
(-34.67)\end{array}$ \\
\hline Herfcaht: Market concentration & $\begin{array}{l}0.144^{* *} \\
(2.048)\end{array}$ & $\begin{array}{c}0.091 \\
(1.279)\end{array}$ & $\begin{array}{c}0.026 \\
(0.356)\end{array}$ & $\begin{array}{c}-0.01 \\
(-0.137)\end{array}$ & & & & \\
\hline Lexport: Exportation & & & & $\begin{array}{l}0.063^{* * *} \\
(14.605)\end{array}$ & & & & \\
\hline $\mathrm{R}^{2}$ & 0.721 & 0.716 & 0.708 & 0.693 & 0.719 & 0.713 & 0.721 & 0.716 \\
\hline $\mathrm{C}$ & $\begin{array}{l}2.865^{* * *} \\
(29.147)\end{array}$ & $\begin{array}{c}2.97^{* * *} \\
(29.857)\end{array}$ & $\begin{array}{l}3.035^{* * *} \\
(29.973)\end{array}$ & $\begin{array}{l}3.009^{* * * *} \\
(28.472)\end{array}$ & $\begin{array}{l}2.595^{* * * *} \\
(29.259)\end{array}$ & $\begin{array}{l}2.575^{* * *} \\
28.7214\end{array}$ & $\begin{array}{l}3.052^{* * *} \\
(32.254)\end{array}$ & $\begin{array}{l}3.104^{* * *} \\
(32.411)\end{array}$ \\
\hline $\mathrm{N}$ & 13419 & 13419 & 13419 & 13419 & 13419 & 13419 & 13419 & 13419 \\
\hline
\end{tabular}

Parameters estimates are standardised with t-values shown in parentheses; ${ }^{* * *}$ Correlation is significant at the 0.01 level, ${ }^{* *}$ Correlation is significant at the 0.05 level, "Correlation is significant at the $10 \%$ level; All the variables begin with "L" are logged.

\section{Appendix 5: Patent Numbers}

\begin{tabular}{ccccccccccc}
\hline Year & 1993 & 1994 & 1995 & 1996 & 1997 & 1998 & 1999 & 2000 & 2001 \\
\hline Patent numbers & 5090 & 5287 & 5511 & 5522 & 5619 & 5384 & 6341 & 6490 & 6206 & 51450 \\
\hline
\end{tabular}

